\title{
TEACHER IMMUNITY IN PROFESSIONAL IDENTITY: REFLECTION ON MALE IELTS TEACHERS' HOMOSOCIAL FABRICS IN 2 IRANIAN ETHNOGRAPHIC INSTITUTIONS
}

\author{
IMUNIDADE DO PROFESSOR NA IDENTIDADE PROFISSIONAL: REFLEXÃO SOBRE OS TECIDOS \\ HOMOSSOCIAIS DE PROFESSORES DE IELTS MASCULINOS EM 2 INSTITUIÇÕES \\ ETNOGRÁFICAS IRANIANAS
}

\section{INMUNIDAD DEL PROFESOR EN IDENTIDAD PROFESIONAL: REFLEXIÓN SOBRE LOS TEJIDOS HOMOSOCIALES DE PROFESORES DE IELTS MASCULINOS EN 2 INSTITUCIONES ETNOGRÁFICAS DE IRÁN}

Fatemeh Mohammad Jafari ${ }^{1}$

Alireza Ameri ${ }^{2}$

\begin{abstract}
As a new concept in language teacher psychology, language teacher immunity is a strong indicator of how teachers behave and respond in the face of disturbances which has a profound effect on teachers' profession. So, as it is apparent, research on language teacher immunity is in its embryonic stage and this qualitative study tried to fill the gap in the existing literature by using Retrodictive Qualitative Modeling to develop an in-depth understanding the experiences of five IELTS male teachers from two ethnographic sites. And due to research and critical studies into men and masculinity has originated as one of the most emerging areas of sociological investigation, on a macro-level of ethnography, this research study concentrated on male IELTS teachers to see the interpretations about masculinity, homosocial relations and desire to make their own professional identity and on the micro-level, the ethos varies at each institution. To achieve the research objectives and answer the questions of this ethnographic study, three data collection techniques were utilized to generate information, namely document collection, classroom observations, and interviews. The findings of this comparative ethnography revealed that in the IELTS situation, "the Visionary" and "The Spark plug" should be placed in two separate groups of immunity (productive and adaptive) to increase the categories of immunity to 5 in this context. So, by adding masculinity patterns, which changed from physicality into knowledge-discipline and socialization-patronage in this study, it was concluded that those who were in productive and adaptive immunity category were not homogeneous due to the fact that they were complicit and approached themselves to the hegemonic masculinity with slight changes that the researchers could not separate them in their immunity.
\end{abstract}

Key words: Teacher immunity, self-organization, homosocial fabrics, professional identity, teachers' cognition.

\footnotetext{
${ }^{1}$ Islamic Azad University, Tehran, Iran.

${ }^{2}$ Islamic Azad University, Tehran, Iran.
} 
Resumo: Como um novo conceito na psicologia do professor de línguas, a imunidade do professor de línguas é um forte indicador de como os professores se comportam e respondem a distúrbios que têm um efeito profundo na profissão dos professores. Assim, como é aparente, a pesquisa sobre imunidade de professores de línguas está em seu estágio embrionário e este estudo qualitativo tentou preencher a lacuna na literatura existente usando Modelagem Qualitativa Retroditiva para desenvolver uma compreensão profunda das experiências de cinco professores do IELTS de dois sites etnográficos. E devido à pesquisa e estudos críticos sobre homens e masculinidade tem se originado como uma das áreas mais emergentes da investigação sociológica, em um nível macro da etnografia, esta pesquisa concentrou-se em professores do IELTS para ver as interpretações sobre masculinidade, relações homossociais e desejo de fazer a própria identidade profissional e no nível micro, o ethos varia em cada instituição. Para atingir os objetivos da pesquisa e responder às questões deste estudo etnográfico, três técnicas de coleta de dados foram utilizadas para gerar informações, a saber, coleta de documentos, observações em sala de aula e entrevistas. Os resultados desta etnografia comparativa revelaram que na situação do IELTS, "o Visionário" e "A vela de ignição" devem ser colocados em dois grupos separados de imunidade (produtiva e adaptativa) para aumentar as categorias de imunidade para 5 neste contexto. Assim, ao adicionar padrões de masculinidade, que passaram de fisicalidade para conhecimento-disciplina e socialização-patrocínio neste estudo, concluiu-se que aqueles que se encontravam na categoria de imunidade produtiva e adaptativa não eram homogêneos pelo fato de serem cúmplices e se aproximarem à masculinidade hegemônica com ligeiras modificações que os pesquisadores não conseguiram separar em sua imunidade.

Palavras-chave: Imunidade docente, auto-organização, tecidos homossociais, identidade profissional, cognição docente

Resumen: Como nuevo concepto en la psicología del profesor de idiomas, la inmunidad del profesor de idiomas es un fuerte indicador de cómo se comportan y responden los profesores ante las perturbaciones, lo que tiene un efecto profundo en la profesión docente. Entonces, como es evidente, la investigación sobre la inmunidad de los profesores de idiomas se encuentra en su etapa embrionaria y este estudio cualitativo trató de llenar el vacío en la literatura existente mediante el uso de modelos cualitativos retrodictivos para desarrollar una comprensión profunda de las experiencias de cinco profesores de IELTS de dos sitios etnográficos. Y debido a la investigación y los estudios críticos sobre los hombres y la masculinidad se ha originado como una de las áreas más emergentes de la investigación sociológica, en un macro-nivel de etnografía, este estudio de investigación se concentró en profesores de IELTS masculinos para ver las interpretaciones sobre masculinidad, relaciones homosociales y deseo de hacer su propia identidad profesional y, a nivel micro, el ethos varía en cada institución. Para lograr los objetivos de la investigación y responder a las preguntas de este estudio etnográfico, se utilizaron tres técnicas de recolección de datos para generar información, a saber, recolección de documentos, observaciones en el aula y entrevistas. Los hallazgos de esta etnografía comparativa revelaron que en la situación del IELTS, "el Visionario" y "La bujía" deben colocarse en dos grupos separados de inmunidad (productiva y adaptativa) para aumentar las categorías de inmunidad a 5 en este contexto. Entonces, al agregar patrones de masculinidad, que cambiaron de fisicalidad a conocimiento-disciplina y socialización-mecenazgo en este estudio, se concluyó que aquellos que estaban en la categoría de inmunidad productiva y adaptativa no eran homogéneos por el hecho de que eran cómplices y se acercaban a sí mismos. a la masculinidad hegemónica con ligeros cambios que los investigadores no pudieron separarlos en su inmunidad.

Palabras clave: inmunidad docente, autoorganización, tejidos homosociales, identidad profesional, cognición docente. 


\section{INTRODUCTION}

The word "identity" is mostly defined by relating people to other members of a group and specifying their participation within that community. The early definition of identity as a social practice might date back to the 1960s and 1970s when interaction between identity and SLA was discussed seriously and conducting research on the relationship between SLA and identity turned into a major trend of study which opened a way for scholars like Beijaard et al. (2004) who introduced professional identity as a separate research area (p.108).

conceptions such as self-efficacy, self-regulated professional development, and intrinsic job motivation that lead to shape EFL teachers' professional identity (Tajeddin \& Khodarahmi,2013).

Yet, understanding the complexities of what language teachers do and why, and the dynamics of how they adapt and develop, is still relatively new in practice. That is why Mercer, Oberdorfer and Saleem (2016) in their book claimed that over the past half a century "learner-centered" approaches have focused on learners, their psychology, behavior, and wellbeing, but it may be time for more of a "teacher-centered" approach in the field of English as a second/foreign language teacher psychology. They expressed their concern in gaps that exist in teachers' psychology. For this reason, in a recent article investigating how the psychological aspects of language teaching interface with the contextual realities of classroom practice, Hiver and Dornyei (2017) introduced the concept of language teacher immunity. The concept of teacher immunity explains the processes through which teachers in general, and language teachers in particular, attempt to come up with a defense mechanism to buffer or moderate the effects of unpleasant disturbances that might threaten their motivation to teach and their professional identity (Hiver \& Dornyei, 2017).

Dealing with perturbations, as Hiver (2017) mentioned, teacher immunity manifests itself in six core language immunity archetypes: L2 teachers may be productively immunized (Visionary and Spark plug), maladaptively immunized (the sell-out, the fossilized), immunocompromised (the over compensator) or they may be defeated who are vulnerable in the perturbations.

As it is perceived, research on language teacher immunity is in its embryonic stage and it needs to be refined by additional investigation (Hiver, 2016). This study, then, sought to find out the dominant type of teacher immunity among Iranian IELTS teachers and to delve into their immunization process to fill the gap in the existing literature on language teacher immunity by adopting the framework of self-organization. To the best knowledge of the researchers and due to the newness of the concept of language teacher immunity, little or no research has been conducted to discover the dominant immunity type and to investigate the developmental process of male IELTS teachers' immunity in Iran.

To emphasize male teachers and considering the fact that gender variation is not only about intergender differences (Bucholtz, 2002), this study also is significant due to its concern toward intra-gender differences because experiential account of men and heterosexuality have been ignored (Appleby, 2014). To clarify men and heterosexuality, there is homosociality in sociology which explains same-sex relationships that are not of a romantic or sexual nature, such as friendship, mentorship, or others. So, the researchers in this study used the concept mainly to explain how male teachers dominant each other in the IELTS classrooms.

Therefore, the first aim of this study was to identify the typical and salient outcomes of language teacher immunity and explore the reasons that informed each of these teacher immunity archetypes.

It also aimed to investigate how teachers' immunity, neglected dimension of $\mathrm{L} 2$ teacher motivation and identity, affect teachers' professional identity. To do so, this study was engaged to see the ways in which intrapersonal factors of identity intersect with contextual and organizational factors in building that identity. To be more precise, this study also tried to explore the ways homosocial fabrics of IELTS male teachers 
affected the kind of immunity they were possessing which resulted in their professional identity. Addressing these purposes in fact involved accomplishing a number of objective which can be formulated as the following research questions:

1. In what ways does teachers' immunity affect their professional identity?

2. How are male homosocial fabric correlated with their immunity and professional identity?

3. What teacher cognition constructs do teachers reveal toward the communicative aspect of IELTS Preparation courses?

\section{METHOD}

This qualitative study intended to develop an in-depth understanding the experiences of five IELTS male teachers from two ethnic groups. Based on what Dornyei (2007) claims about ethnography that "embodies in many ways the essence of the qualitative inquiry" (p. 129), and due to inherent interest of applied linguistics in intercultural communication, it is deemed as the favorable and practical method for this study. In this situation data are text-based which can easily interpret complexities of social phenomena and can uncover beliefs, values, and motivation underlie individual behavior.

Engaging in qualitative research methods to data collecting and analysis has significantly increased over the past two decades. Qualitative researchers underline the socially constructed nature of reality. They actually try to find seemly answers to questions that highlight how social experience is created and given meaning (Denzin \& Lincoln, 1998, p. 8). Thus, applying a constructivist approach within qualitative method of inquiry allows for the study of the "how-and sometimes why-participants construct meanings and actions in specific situations (Hallberg, 2006). By preserving a "beginners mind", a mind that is willing to see everything as if for the first time, the qualitative researchers support a procedure which is supreme for explorative study of a new, or relatively new, social experience (Kabat-Zinn, 1990). So, because there exists little research on the topic, qualitative inquiry and analysis fit this purpose with stronger sensitivity than a quantitative methodology could offer. To proceed, this research was conducted ethnographically set in two coeducational language institutions that are differentiated on the basis of the social characteristics of their intake. Diako Language Academy was situated in North East with 15 years of experience and Milad Language College in West of Tehran.

Exploring and examining culture and society need personal involvement in the location, which is the key issue in the fieldwork enquiries. Therefore, based on extended fieldwork which punctuates going through sufficient time, the research took place from Aban 1398 to Ordibehesht 1399.

On a macro-level of ethnography, this research study concentrated on male IELTS teachers to see the interpretations about masculinity, homosocial relations and desire to make their own professional identity.

On the micro-level, the ethos varies at each institution. Diako Language Academy marketed itself on academic achievement and presenting high educational quality. They are not competitive and do not consider others as rivals. They believe in innovation along with being active in the group. In contrast, the main focus of Milad Language College was excessive publicity and efforts to augment teachers' works and the quality of education and making propaganda of humanity.

Admittedly, one can see how comparisons could help the researchers better recognize changing patterns of interaction across space. Focusing on discrete field sites, also reveal how concepts of teaching could have different meaning across language groups within regions. So, by comparative ethnography in small size, this ethnographic research explicitly and intentionally built an argument through the analysis of 
these two cases. The researchers in fact, intentionality and explicitly were in tacking back and forth across similarities or differences to develop theoretical arguments.

\section{Participants}

In line with qualitative studies which usually focus on a small number of individuals, this ethnographic project did not allow the researchers to study large numbers of people, or limitless numbers of events. Therefore, they detected characteristics of five male teachers from two separate sites who were invited to participate in this study to investigate the world of male teachers through their own words while they were practicing IELTS.

Following that, the first element in this study that determined the boundary was the study sampling. Only 5 IELTS teachers formed the primary unit of analysis. The second element comprised of two sites. The first was DIAKO Language Academy where two of them joined 5 years ago to practice IELTS teaching in North of Tehran. The second was MILAD Language College where the other three have been colleagues for 8 years to practice both pre-IELTS and IELTS courses. The following table shows the demographic information of these IELTS teachers.

\section{Instrumentation and Data collection procedures}

To achieve the research objectives and answer the questions of this ethnographic study, three data collection techniques were utilized to generate information, namely document collection, classroom observations, and interviews. These were the three crucial methods of gathering data in any qualitative study to enhance the data credibility (Yin, 2011).

Since there were some behaviors, ideas, thoughts, and general information belonging to the teachers that could not be elicited throughout the class observation time, the researchers effaced this drawback through the second dimension of Triangulation, Interview. The questions fell into the category of semistructured interview to make teachers free to follow their own path. To ensure an accurate and detailed record of actual language, data were audio-recorded and transcribed. For naturally occurring texts extended from interview data, content analysis was considered, too. Thus, the researchers' descriptions and interpretations were based on two major sources of data: first, their $r$ semi-participant observations of teachers during lessons and around the institution sites, and second, a series of loosely structured interviews.

Next, with regard to teacher' gender identity, the field of language and gender studies has been slow to include a focus on masculinity and its complexities and the way in which gender intersects with ethnicity in the construction of teachers' professional identity. Therefore, the present study aimed at realizing the developmental process of teacher professional identity through understanding immunity among Iranian IELTS teachers by adopting the framework of Swain (2006) which are:

- Hegemonic: the leading form on show

- Complicit: Followers, imitators but without any real power or influence

- Personalized: Culturally authoritative form of masculinity within each setting.

- Subordinated: Victimized and pursued

In other word, this study argued the differentiation between masculinity categorization of two institutions under study on the basis of the social characteristics of their male IELTS teachers. So, this study 
focused on how male IELTS teaches in two different ethnic groups construct their professional identity which correlated with their immunity and homo-social fabrics. The following demonstrates male teachers' homosocial fabric in relation to their immunity archetypes.

Table 1. Teachers' Homo-social fabric

\begin{tabular}{|c|c|c|c|c|c|c|c|}
\hline \multirow{6}{*}{ 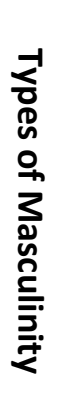 } & \multicolumn{7}{|c|}{ Language Teacher Immunity Archetypes } \\
\hline & & $\begin{array}{c}\text { The } \\
\text { Visionary }\end{array}$ & $\begin{array}{c}\text { The Spark } \\
\text { plug }\end{array}$ & $\begin{array}{c}\text { The } \\
\text { fossilized }\end{array}$ & $\begin{array}{c}\text { The } \\
\text { Defeated }\end{array}$ & Sell-Out & $\begin{array}{c}\text { Over- } \\
\text { compensator }\end{array}$ \\
\hline & Hegemonic & & & & & & \\
\hline & Complicit & & & & & & \\
\hline & Personalized & & & & & & \\
\hline & Subordinated & & & & & & \\
\hline
\end{tabular}

\section{Design and procedure of the study}

Within this qualitative study, retrodictive qualitative modeling was used. RQM is a process by which the researchers identified the end-states in system behavior and then worked backwards in a retrospective manner to uncover the developmental trajectories that led to those settled states. In other words, by the help of RQM the researchers tried to identify the main emerging system prototypes. To do so, they worked 'backwards' and pinpointed the principal factors that had led to the specific settled states. In other words, instead of the usual forward-pointing 'pre-diction' in the research, the researchers reversed the order of things and pursue 'retro-diction' by tracing back the reasons why the system (teachers) had ended up with a particular outcome.

By and large, within the elemental coding methods, descriptive, thematic, and team coding seemed more amenable for this study. Descriptive/ structural coding allows the data to be coded and is particularly useful for transcription to describe topic and compare the data with inter-coders for deeper analysis.

Therefore, for the purpose of data analysis of this study, Braun and Clarke's (2006) six phases of thematic analysis was chosen:

1) familiarizing with data, 2) generating initial codes, 3) searching for themes,4) reviewing themes,

5) defining and naming themes, and 6) producing the report.

These phases were used as a guide to provide a straightforward step-by-step way to conducting the thematic analysis.

For the purpose of analysis, the researchers did according to grounded theory. Categories related to homosocial fabrics were generated from the observation field notes and the interview transcriptions. The final labels for all immunity archetypes were chosen from director of studies interview data. To do this, parallels in the background literature were examined for a more theoretically grounded classification of each teacher type; from the director of studies interviews, 7 constructs were found to be essential to the makeup of all archetypes: teaching self-efficacy, attitudes to teaching, coping, classroom affectivity, burnout, resilience, and openness to change. During the analysis, the archetype case nodes were then elaborated by categorizing their descriptive characteristics into these seven constructs, combining overlaps, and eliminating redundancies. Commonalities and differences in practice between participants were noted in the observational data and triangulated with data from the interviews which added depth by revealing the men's understanding of those aspects of their practice that were similar or different to teachers in another ethnic 
group. Behaviors which were found in at least four of the five cases were defined as common practice, and served as the basis for the major conclusions of the research. Commonalities were the target of the research; whose goal was to identify common aspects of gender identity formation through practice in different cultures. The observed differences enabled an analysis of how these common gender identity issues found expression in different cultures. Findings Each common practice among the participants presented below.

\section{DATA ANALYSIS}

\section{Teachers' system immunity in IELTS courses}

Language teacher immunity, either in its productive or maladaptive pattern, is a state that language teachers settle in after the process of self-organization. Therefore, in order to grasp more comprehensive view toward different aspects of IELTS teachers' immunity in this study in depth, research question "In what ways does teachers' immunity affect their professional identity?" and "What teacher cognition constructs do teachers reveal toward the communicative aspect of IELTS Preparation courses?" went hand in hand to be analyzed at one place. So, with regard to four stages of self-organization (triggering, linking, realignment, and stabilization), based on observation analysis and interviews done, the researchers went through IELTS teachers' immunity archetypes in both ethnographic sites. The following table provides a general overview of the issue.

Table 2. Teachers' immunity types in IELTS course

\begin{tabular}{|c|c|c|}
\hline \multirow{2}{*}{ 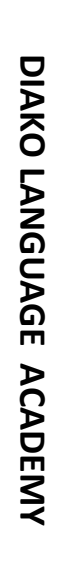 } & Teacher A & $\begin{array}{c}\text { The Visionary } \\
\text { - Tremendously positive attitude toward IELTS teaching and test. } \\
\text { • Supreme openness to change } \\
\text { • Exceptionally high level of teaching self-efficacy. } \\
\bullet \text { Remarkable coping skill and resilience } \\
\text { - Tremendously positive affection in his classroom. }\end{array}$ \\
\hline & Teacher B & $\begin{array}{c}\text { The Visionary } \\
\text { - Tremendously positive attitude toward IELTS teaching and test } \\
\bullet \text { Supreme openness to change } \\
\text { • Exceptionally high level of teaching self-efficacy } \\
\text { • Remarkable coping skill and resilience. } \\
\text { - Tremendously positive affection in his classroom }\end{array}$ \\
\hline \multirow{2}{*}{ 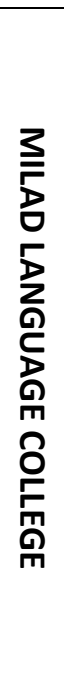 } & Teacher A & $\begin{array}{c}\text { The Spark Plug } \\
\text { - average attitude toward IELTS test and teaching } \\
\text { - Having strong teaching self-efficacy } \\
\text { - Having considerable coping skill and resilience } \\
\text { - Being open to changes } \\
\text { - Having job commitment } \\
\text { - High levels of burnout }\end{array}$ \\
\hline & Teacher B & $\begin{array}{c}\text { The Fossilized } \\
\text { - Having unsure attitude toward IELTS test and teaching } \\
\text { - Trying to be open to changes but still be averse to them } \\
\text { - Moderate amount of teaching self-efficacy } \\
\text { - Reluctant to take risk } \\
\text { - Moderate level of burnout and resilience } \\
\bullet \text { Having job commitment }\end{array}$ \\
\hline
\end{tabular}




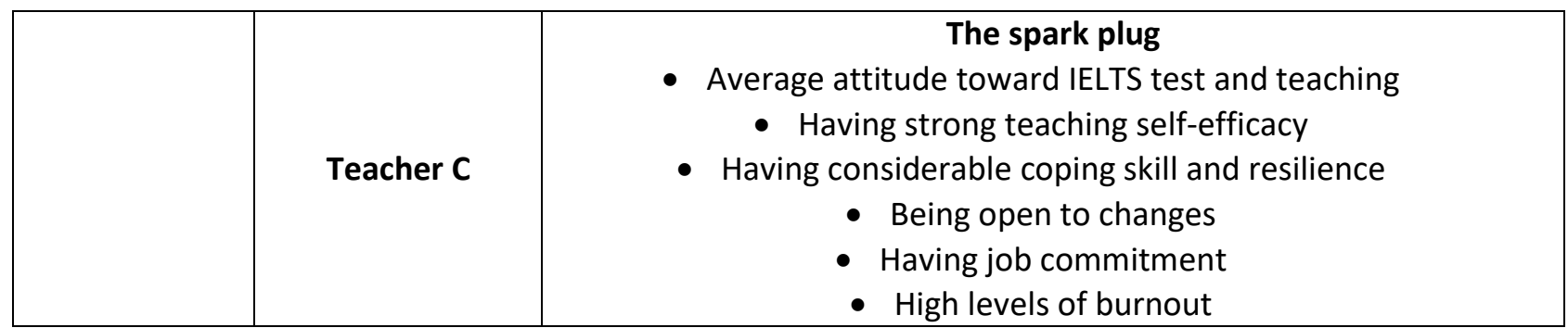

First of all, for triggering stage of self- organization, the interview data of the study revealed two types of stressors in organizational and personal level for teacher A at Milad Language College. Teacher A possessed negative attitude toward this test due to his hatred for this test being too tricky and ambiguous in some points which causes financial abuse to occur. He also believed that some topics were "really dull, drily, nonsensical, and not even worth discussing", so both students and teachers were bothered how to overcome the topics. To him, "they were too unrealistic to be function-based". He added the overall reasoning of this test is communicative competence but due to the existence of 4 criteria, students and teachers devote more attention to piece of language in it and he considered it as a problem. However, he really enjoyed developing students' competency in IELTS writing and speaking.

Through coupling stage, the language teacher goes thorough change and adaptability. So, for teacher A, although he had problem not taking any form of training, he had tried to self-study and self-train himself by reading different books and also watching different trainers online. Based on what he claimed, he was trying to read different kinds of methodology books to tailor them to teaching IELTS and remain open to newness and receptive to innovating in IELTS writing and speaking. As a consequence, according to researchers' observations in writing classes, he tried too much because of his commitment to the profession and he expected to have active students who were using provided organized language to interact with peers and the teacher.

As for realignment stage of self-organization, he had high levels of burnout because he considered himself as an organizer in the class. He thought he needed to be a language provider to provide source and help students to take care of problems and make progress to open up space for interaction and communication by using the language. Considering observations, exactly like a manager he would give every individuals feedback to their works in and outside the classroom.

To researchers' observation. as he believed during the course, he thought successful students should have plan to study and practice what they are preached to write systematically. So, this idea was accordance with what he was doing in the classroom which would eliminate authenticity and creativity of students' works. Therefore, based on the stabilization stage that can also be called identity reconstruction stage, teacher $\mathrm{A}$ has brought this idea severely into his professional identity.

When it comes to triggering stage, from the very beginning teacher B took the position of being unsure towards IELTS test. However, he thought to be the best in the classroom a teacher you have to consider optimum goal by which all the plans and activities are designed to achieve it. He couldn't see much reasoning for its highly focused domain nowadays and believed time span would say if it could still work best or not.

By looking at coupling and realignment stages of self-organization, according to both interview and observation data teacher B was trying to be open to changes but except for some points (productive tasks), he was still averse to them. "I have attended some great workshops, however, I am dead sure, the personal experiences can be a good and valuable help to improve teaching." In another question, in terms of ruling 
the class, he answered, "I have always tried to take the role of facilitator yet, sometimes the class makes me decide where and when to do things and how!"

Moreover, for stabilization stage of self-organization, in the classroom teacher B possessed acceptable amount of teaching self-efficacy due to his best try to teach, in other words, job commitment to the class, and poor students' productions made him experience acceptable amount of self-efficacy. In this situation, although he tried to deal effectively with the course, he couldn't overcome the problems completely and he got angry and changes in tone of his voice were perfectly obvious.

Regarding triggering and linking stage, as an IELTS instructor, teacher C's attitude toward this test was negative due to financial issues. He believed that the philosophy behind this test was more monitory and marketing than being academic or job-related. That was why he used the terms "prestige" and "profitability" for his choice of action in teaching this course. Yet, to him, teaching it had brought self- satisfaction and enjoyment because he could help his students to achieve their goals perfectly.

Having repertoire of strategies for the purpose of realignment, with high level of burnout and resilience, in the classroom by the help of guided participation, teacher $C$ provided a situation for students to move from being passive to be more active and take responsibility for their own learning. To do so, he stayed himself open to changes outside the classroom by attending to different workshops and this provided him new and inventory materials and tasks to motivate students to move forward which demonstrated his job commitment to IELTS classes and students.

As it was highlighted before, for his professional identity in stabilization stage of self-organization, he mentioned of having strategic plan due to the fact that many IELTS candidates have limited time, so they require a shortcut to master IELTS faster. By doing so, he would eliminate creativity and authenticity factor in the classroom.

With regard to attitude, teacher A at Diako Language Academy had tremendously positive attitude toward both IELTS teaching and test. To him, this test is the one with regular basis and high reliability which has compiled standards.

To consider triggering and coupling stage of his self-organization process, teacher A had passed different training courses regarding IELTS and know how to overcome the problems in this course. Based on what he claimed these courses had changed his vision toward IELTS in general and in particular teaching writing. He thought this was the students who were to produce and develop ideas and "as a teacher in order to make students produce both writing and speaking we had to open up a critical thinking situation, allocate enough time and energy for students' preparation, practice and retention to grow in confidence". Correspondingly, to researchers' observation, he was experiencing remarkable tolerance toward students' deficiency during the class time.

Besides, as his teaching strategy in realignment stage of self-organization, due to communicative nature of this test, with teaching authentically and creatively, he tried to have formative assessment during the course to point tips and techniques. Having hidden plan, students were supposed to create the real situation in which teaching could happen. Promoting creativity and authenticity among students to find their own voices along with being compassionate and affectionate to each one of them made him feel exceptionally high self-efficacy which has been part of his professional identity in stabilization stage of selforganization.

Teacher B was one of the advocates of authentic teaching and creative thinking. So, this has become part of his professional identity within self- organization development. He thought IELTS test was one of the fair and intellectual exams which was highly acceptable and communicative in which there were set goals for 
each skill. He believed by giving students different sources teachers could promote a situation for student' autonomy and creativity to produce authentic paragraphs in writing.

In terms of triggering and coupling stage of self-organization, to eliminate rater' subjectivity, he allocated enough time and energy to provide a real situation for students to practice and have an overall view toward the topic. In this situation based on the results obtained from the content analysis his students could bridge the possible gaps in raters' minds.

Paying attention to realignment stage of self-organization development, through passing different workshops and learning ins and outs of this test, he was confident enough to help students pass this exam successfully and creatively. Having hidden plan, he could adjust his mind according to each one of the students' creation in the class. This situation promoted compassion and affection among the teacher and students.

In terms of burnout and resilience, by the help of cooperation and patience he knew how to overcome students'problems together in writing.

\section{IELTS teachers' homo-social fabric}

To answer the second research question of the study "How are male teachers' homo-social fabric correlated with their immunity and professional identity?", the analysis started with each common practice among the teachers with supporting data from the results obtained in analyzing research question 1 . Based on these practices, a model of how IELTS male teachers constructed their professional identity offered.

Although the terms "hegemonic," "complicit," "subordinate", and "Personalized" masculinity were borrowed from Swain (2006), the researchers found it necessary to change the concept of physicality and athleticism of masculinity to Knowledge and Discipline, Socialization, and Patronage of masculinity.

While studies show that most men fall short of societal ideals of hegemonic masculinity, over time, the influence of men's masculinity replicated by their teaching style. This deconstruction of the idealized men's model came at the expense of certainty in knowing what it means to be a good teacher. Form the both observation and interviews, the researchers found that there were different patterns of masculinity both between and within each setting that drew on the resources, documents, and transcripts. So, they discussed the way the research was theorized, particularly in relation to the concept of hegemonic masculinity and its link with knowledge and discipline, socialization and patronage. The following figure clearly demonstrates the changes found in this study. 


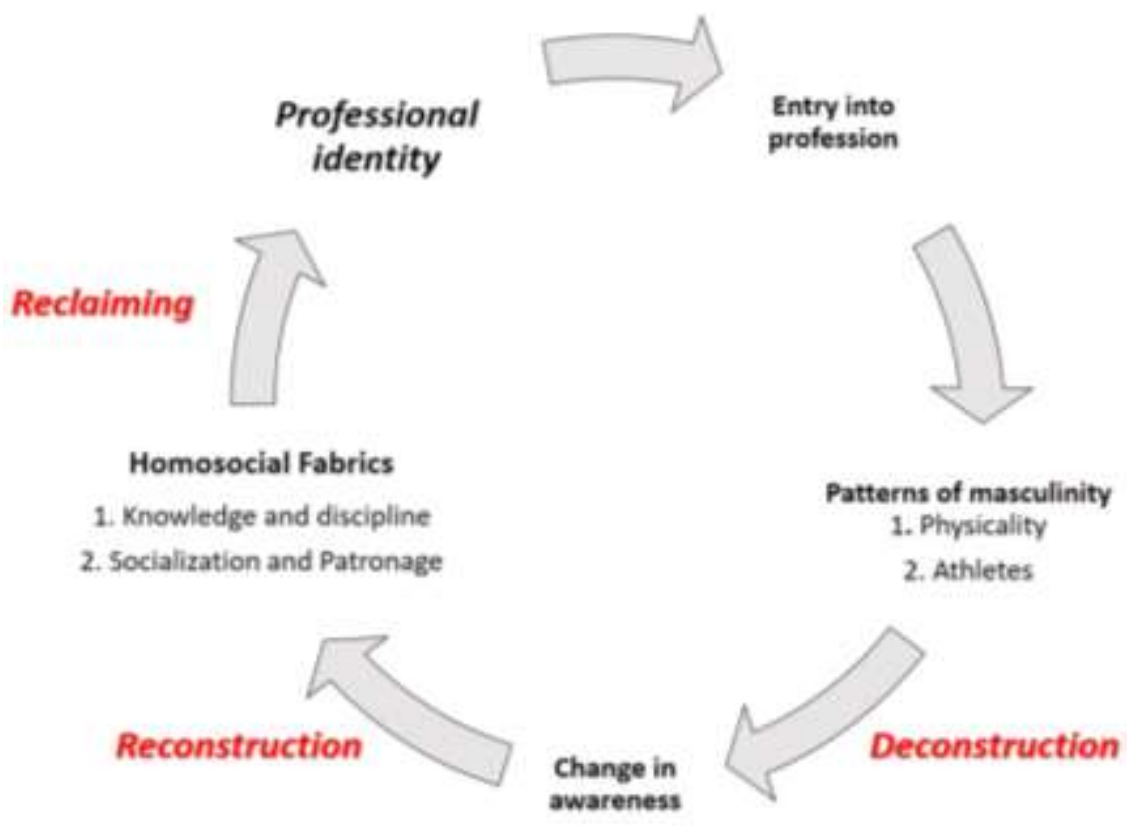

Figure 1. Formation of professional identity through homosocial fabrics among male IELTS teachers

The dominant pattern of masculinity at MLC (knowledge and discipline) belonged to what teacher A performed and he was aware of its significance. Personally and socially it was seen as the most acceptable and desirable way of being a male teacher in that ethnographic site.

Based on the observations and interviews, the idealized form of masculinity manifested itself in teacher A with the "spark plug" type of immunity and both teacher B and C were the ones who joined him and were closely connected to him. They tried to embody many of the qualities and traits of teacher A in teaching without ever being one of the "frontline troops". Therefore, teacher B and C practiced complicit pattern who lacked a sufficient number of knowledge and discipline features to be accepted into hegemonic form.

To be more specific, with regard to teacher C's efforts with the "spark plug" type of immunity, despite his attempts, he was found to be tolerated instead of being really accepted and was pushed periphery.

However, teacher B with fossilized type of immunity had no desperate urge to become teacher A, because the simple fact was that even if he wanted, he had a deficit to succeed at the highest level. He actually possessed some features of Subordinated, but the researchers preferred to place him into complicit pattern in lower order due to his considerable efforts in teaching.

Indeed, teacher $B$ and $C$ who the researchers classified exhibiting complicit could not be seen hanging around the edge of teacher A, watching his actions. They were in fact, "wannabe".

Considering knowledge as the main factor for hegemonic masculinity at MLC, both teacher $A$ and $B$ with "the visionary" type of immunity at DLA were considered knowledgeable in IELTS teaching; however, the dominant form of masculinity and it feature fitted teacher B's efforts in socializing with students which encompassed patronage. His common sense also was seen as the most acceptable and desirable way of being an IELTS male teacher in this ethnographic context.

However, for teacher A, although he was generally also good at socialization with his students and had any number of qualities, he didn't have enough of what his colleague had to make his performance accepted to have a patronage. He was good, but not good enough. From his accounts, he would have liked 
to have been dominant, but despite his attempted ingratiation, he found himself periphery. Therefore, based on the observations and interviews, teacher A was found to practice in complicit pattern of masculinity.

Table 3. The Different Forms of Masculinity and Their Main Features at site

\begin{tabular}{|c|c|c|c|c|c|}
\hline \multicolumn{3}{|c|}{ Diako Language Academy } & \multicolumn{3}{|c|}{ Milad Language College } \\
\hline & Teacher $A$ & Teacher B & Teacher A & Teacher B & Teacher C \\
\hline $\begin{array}{l}\text { Hegemonic } \\
\text { (The leading } \\
\text { form) }\end{array}$ & & $\begin{array}{l}\text { Top teacher, } \\
\text { based on the } \\
\text { resources of } \\
\text { socializing and } \\
\text { having } \\
\text { patronage } \\
\text { among students. } \\
\text { - Enjoyment of } \\
\text { students } \\
\text { - Patience and } \\
\text { determination } \\
\text { Acceptance of } \\
\text { individuals }\end{array}$ & $\begin{array}{l}\text { Top teacher, } \\
\text { based on the } \\
\text { resources of } \\
\text { having } \\
\text { knowledge and } \\
\text { discipline } \\
\text { - Having plan } \\
\text { - Joining } \\
\text { associations } \\
\text { - Making the } \\
\text { most of } \\
\text { resources } \\
\text { and training } \\
\text { opportunities }\end{array}$ & & \\
\hline $\begin{array}{l}\text { Complicit } \\
\text { (Imitators but } \\
\text { without any } \\
\text { real power or } \\
\text { influence) }\end{array}$ & & $\begin{array}{l}\text { Follows the } \\
\text { idealized form } \\
\text { and tries his best } \\
\text { to do the same } \\
\text { activities and he } \\
\text { was to some } \\
\text { extend } \\
\text { successful but } \\
\text { not still included. }\end{array}$ & & $\begin{array}{l}\text { Follows the } \\
\text { idealized } \\
\text { form; tries to } \\
\text { do the same } \\
\text { activities but } \\
\text { due to his } \\
\text { poor } \\
\text { knowledge } \\
\text { and not being } \\
\text { updated, he } \\
\text { does not have } \\
\text { sufficient } \\
\text { capability to } \\
\text { be included. }\end{array}$ & $\begin{array}{l}\text { Follows and } \\
\text { imitates the } \\
\text { idealized } \\
\text { form; tries to } \\
\text { do the same } \\
\text { activities but } \\
\text { do not have } \\
\text { sufficient } \\
\text { capability to } \\
\text { be included, } \\
\text { but benefit } \\
\text { from " } \\
\text { patriarchal } \\
\text { dividend". }\end{array}$ \\
\hline \multicolumn{6}{|l|}{$\begin{array}{c}\text { Personalized } \\
\text { (monodominant } \\
\text { but active) }\end{array}$} \\
\hline $\begin{array}{c}\text { Subordinated } \\
\text { (Victimized and } \\
\text { pursued) }\end{array}$ & & & & & \\
\hline
\end{tabular}

\section{DISCUSSION AND CONCLUSION}

According to the purpose, this study endeavored to find out the dominant type of teacher immunity, either productive or maladaptive, among IELTS teachers in two ethnographic sites and to delve into the immunization process. However, although the immunity archetypes that the researchers used were appropriate from Hiver (2017), they also found some of his theorizing on immunity insufficient to describe moderates in IELTS settings and the data that the researchers uncovered persuaded them to propose another type. To do so, they changed the extreme adjectives to moderate ones to distinguish visionary from spark plug, and fossilized archetypes and it led them to a new immunity type "adaptively immunized". 
Therefore, based on the findings in this study, 2 of the teachers from Diako Language Academy, fell into productively immunized type and from 3 of the teachers under study at Milad Language College, 2 of them were placed in newly proposed type adaptively immunized and the other teacher was recognized to be in maladaptively immunized type in the context of IELTS teaching in Iran.

Therefore, based on the meanings of productive, adaptive, and maladaptive, with regard to immunity, IELTS teachers in Iran with visionary archetype would fall into productively immunized, teachers with spark plug archetypes in adaptively immunized, and fossilized ones belong to maladaptively immunized type. To put it in another word, the results showed that in the IELTS situation, "the Visionary" and "the Spark plug" should be placed in two separate groups of immunity (productive and adaptive) to increase the categories of immunity to 5 in this context.

As it was perceived, patterns of masculinity were context specific. There were similarities and differences between them, and these were the result of the different meanings and practices at each institution that in turn gave rise to the series of different options and opportunities of learning the meanings of male IELTS teacher in both settings. Although each hegemonic pattern had its own distinctive features in each institution setting, the overriding characteristic that the hegemonic forms have in common was that they inevitably establish themselves around the knowledge. Also, by adding masculinity patterns, which changed from physicality into knowledge-discipline and socialization-patronage in this study, it was concluded that those who were in productive and adaptive immunity category were not homogeneous due to the fact that they were complicit and approached themselves to the hegemonic masculinity with slight changes that the researchers could not separate them in their immunity.

\section{Pedagogical Implications}

It is assumed that the results of this study can be implicated for IELTS teacher educators to open a file for teacher immunity concept considering self-organization stages while they are trying to educate teachers for teaching skills inside the classroom. Therefore, further research can be done with more than 5 subjects which might bring about new findings. Also, in this study, the process of teacher immunity, was conducted qualitatively, other studies can benefit from measuring this concept through suggested questionnaire from Hiver (2017).

\section{REFERENCES}

Appleby, R. (2014). Men and Masculinities in Global English Language Teaching ( $1^{\text {st }}$ edition). Palgrave Macmillan.

Braun, V., \& Clarke, V. (2006). Using thematic analysis in psychology. Qualitative Research in Psychology, University of West England, 3 (2), 77-101.

Beijaard, D., Meijer, P., \& Verloop, N. (2004). Reconsidering research on teachers' professional identity. Journal of Teaching and Teacher Education, 20 (2), 107-119.

Denzin, N. K., \& Lincoln, Y. S. (1998). Entering the field of qualitative research. In N. K. Denzin \& Y. S. Lincoln (Eds.). Collecting and interpreting qualitative materials (pp.1 - 34). Thousand Oaks, CA: Sage.

Dornyei, Z. (2007). Research methods in applied linguistics. Oxford New York: Oxford University press. P. 129-147-160-161. 
Dias, A. F. (2020). Trans* escrevivências as a pedagogical power. Journal of Research and Knowledge Spreading, 1(1): 1-17.

Hiver, P. (2017). Tracing the Signature Dynamics of Language Teacher Immunity: A Retrodictive Qualitative Modeling Study. The Modern Language Journal, (101)4, 669-690.

Hiver, P., Dörnyei, Z. (2017). Language Teacher Immunity: A Double-Edged Sword. Applied Linguistics, 38(3), 405-423.

Heckler, V. et al. EClnvestigation with experimental practical activities in training geographically distant teachers. Journal of Research and Knowledge Spreading, 1(1): 1-15.

Bucholtz, M. (2002) "From sex differences to gender variation in sociolinguistics.," University of Pennsylvania Working Papers in Linguistics, 8 (3), 33-45.

Kabat-Zinn, J. (1990). Full catastrophe living: Using the wisdom of your body and mind to face stress, pain, and illness. Journal of International Education Studies, 10(9), 1-8.

Hallberg, L. M. R. (2006). The "core category" of grounded theory: Making constant comparisons. International Journal of Qualitative Studies on Health and Well-being, 1(3), 141-148.

Mercer, S., Oberdorfer, P., \& Saleem, M. (2016). Helping language teachers to thrive: Using positive psychology to promote teachers' professional well-being. In D. Gabryś-Barker \& D. Gałajda (Eds.), Positive psychology perspectives on foreign language learning and teaching (pp. 213- 229). Switzerland: Springer International Publishing.

Paraskeva, J. M. (2016). "Brutti, Sporchi \& Cattivi": Towards a Non-Abyssal Curriculum. Revista Tempos E Espaços Em Educação, 9(18), 75-90.

Swain, J. (2006). Reflections on Patterns of Masculinity in School Settings, Journal of Men and Masculinities, 8(3), 331-349.

Tajeddin, Z., \& Khodarahmi, E. (2013). EFL teachers' professional identity: Underlying components and factors contributing to its construction. Paper presented at the $11^{\text {th }}$ TELLSI International Conference, Mashhad, Iran.

Yin, R. K. (2011). Qualitative research from start to finish. (2 ${ }^{\text {nd }}$ ed.). New York: Guilford.

\section{ABOUT THE AUTHORS}

Fatemeh Mohammad Jafari

Ph.D student. Department of Foreign Languages, Central Tehran Branch, Islamic Azad University, Tehran, Iran.

Email: Fatemeh m jafari@yahoo.com.

ORCID: https://orcid.org/0000-0003-4127-7906

\section{Alireza Ameri}

Assistant Professor. Department of Foreign Languages, South Tehran Branch, Islamic Azad University, Tehran, Iran.

*Corresponding autor, E-mail: a ameri@azad.ac.ir,

ORCID: https://orcid.org/0000-0002-0741-5124 
Received on: 09-10-2020

Approved on: 11-10-2020

Published on: 11-23-2020 